\title{
EXPERIMENTAL STUDIES ON BEARING CAPACITY OF SKIRTED FOOTINGS ON C-Ф SOILS
}

\author{
Arekal Vijay $^{1}$, Vijayalakshmi Akella ${ }^{2}$, PR Bhanumurthy ${ }^{3}$ \\ ${ }^{1}$ Department of Civil Engineering, KS School of Engineering and Management, 15, Mallasandra, Bengaluru, \\ Karnataka 560062, India \\ ${ }^{2}$ Department of Civil Engineering, KS School of Engineering and Management, 15, Mallasandra, Bengaluru, \\ Karnataka 560062, India \\ ${ }^{3}$ Department of Civil Engineering, JNTU College of Engineering, Anantapur, Andhra Pradesh 515002, India
}

\begin{abstract}
This study has examined the effect of vertical insertions or skirts on bearing capacity of bucket foundations or skirted footings on $c-\Phi$ soils. The parameters included thickness and depth of vertical insertions or skirts and the shape of footings. The pressuresettlement curves showed that thickness and depth of vertical insertions improves bearing capacity and in some cases the improvement is up to eight times. The shape of the footings also has effect on bearing capacity of c- $\Phi$ soils. The improvement in bearing capacity of square shaped skirted footings were found to be higher than the circular and rectangular shaped footings with vertical insertions.
\end{abstract}

Keywords: Skirted Footings, Bucket Foundations, Confined Footings, Bearing Capacity, Settlement, Shear Failure, Vertical Insertions.

\section{INTRODUCTION}

The various methods of improving bearing capacity of footings has been discussed in the engineering literature. The present study focus on improving the bearing capacity of foundations by foundation soil confinement. The confinement of foundation soil is achieved by providing vertical plates or insertions along the periphery of footings. These vertical plates prevent the lateral movement of foundation soil under the load from superstructure. These vertical plates or insertions are termed as skirts and foundations with these skirts are commonly referred as skirted footings or bucket foundations. These foundations are commonly employed in offshore structures to replace deep foundations. However, skirted foundations are yet to find its place in onshore structures. Many researchers have carried out works on these type of foundations for onshore conditions. The earlier research works mainly focused on footings on sand or granular soils. The present study focused mainly on bearing capacity of skirted footings on c- $\Phi$ soils.

Laboratory testing was carried out by S.GolmoghaniEbrahimi et al to study the bearing capacity of shallow skirted foundation (SSF). The effect of skirt thickness and skirt depth on bearing capacity of skirted models were studied. Test results were compared with analytical values obtained from bearing capacity equations and found that structural skirts improves bearing capacity. It was also found that bearing capacity was higher for flexible skirts and rigid skirts have no significant effects on bearing capacity. The bearing capacity of skirted footing was to be 2.91 to 3.68 times higher than the foundations without skirts.
An experimental study to find the horizontal load carrying capacity of shallow skirted foundation (SSF) was carried by S.P. Singh et al. In their study, the effect of skirt length and relative density of sand beds on horizontal load carrying capacity of SSF in sand were investigated. Bearing capacity tests were conducted on varying relative density of $30 \%$, $45 \%, 60 \%, 75 \%$ and $90 \%$ and different skirt length to depth ratio of $0.4,0.6,1.2,1.5 \& 2.0$. Test results showed that there was a significant improvement in horizontal load carrying capacity when the relative density is more than $60 \%$.

To study on the behaviour of skirted foundation subjected to uplift and compression pressure have carried out by Hugo et al. The objective of studies was to improve the designs for jacket structures to resist extended periods of harsh seasonal weather or loop currents. The centrifuge tests were carried on a shallow skirted foundation in clay. Rapid and sustained loading were considered for the test and the effects of consolidation stress level and stress history on undrained capacity and sustained load response were analysed. The findings indicate that the uplift resistance is less robust than the compression response and caution should be taken while designing against uplift. They found undrained tension capacity is more sensitive to loading history than undrained compression capacity. Failure in uplift under sustained loading is found to be preceded by a marked acceleration in the displacements.

In the present paper we report results of experiments which were designed to provide information on the pressuressettlement curves for skirted footings on c- $\Phi$ soil. 


\section{MATERIALS AND METHODS}

\subsection{Footings}

Model footings of various shapes made up of mild steel are used for testing. The footings sizes are smaller than (1/5) B (where $\mathrm{B}=$ least lateral dimension of container) to avoid lateral confinement effect. The details of the model footings are given in Table 1 . The thickness of model footing was 10 $\mathrm{mm}$ and fabricated from mild steel. The plan area of the model footings kept constant at $3,600 \mathrm{~mm}^{2}$ for all shapes. Fig. 1 shows the model footings and the loading system of the model footings considered in this investigation. The insertion depths varied between $0.5 \mathrm{~B}$ to $1.5 \mathrm{~B}$.

Table 1: Model footing dimensions

\begin{tabular}{|c|c|c|c|c|c|}
\hline \multirow[t]{2}{*}{$\begin{array}{l}\text { Sl. } \\
\text { No }\end{array}$} & \multicolumn{3}{|c|}{$\begin{array}{l}\text { Footing size } \\
(\mathrm{mm})\end{array}$} & \multirow{2}{*}{$\begin{array}{l}\text { Vertical } \\
\text { insertion } \\
(\mathbf{m m})\end{array}$} & \multirow{2}{*}{$\begin{array}{l}\text { Thickness of } \\
\text { vertical } \\
\text { insertion } \\
\text { (mm) } \\
\mathrm{T}\end{array}$} \\
\hline & $\mathrm{L}$ & B & $\mathrm{T}$ & & \\
\hline 1 & \multirow{3}{*}{60} & \multirow{3}{*}{60} & \multirow{3}{*}{10} & $0.5 \mathrm{~B}$ & 1 \\
\hline 2 & & & & $1.0 \mathrm{~B}$ & 1 \\
\hline 3 & & & & $1.5 \mathrm{~B}$ & 1 \\
\hline 4 & \multirow{3}{*}{60} & \multirow{3}{*}{60} & \multirow{3}{*}{10} & $0.5 \mathrm{~B}$ & 3 \\
\hline 5 & & & & $1.0 \mathrm{~B}$ & 3 \\
\hline 6 & & & & $1.5 \mathrm{~B}$ & 3 \\
\hline 7 & \multirow{3}{*}{60} & \multirow{3}{*}{60} & \multirow{3}{*}{10} & $0.5 \mathrm{~B}$ & 5 \\
\hline 8 & & & & $1.0 \mathrm{~B}$ & 5 \\
\hline 9 & & & & $1.5 \mathrm{~B}$ & 5 \\
\hline 10 & \multirow{3}{*}{40} & \multirow{3}{*}{90} & \multirow{3}{*}{10} & $0.5 \mathrm{~B}$ & 1 \\
\hline 11 & & & & $1.0 \mathrm{~B}$ & 1 \\
\hline 12 & & & & $1.5 \mathrm{~B}$ & 1 \\
\hline 13 & \multirow{3}{*}{40} & \multirow{3}{*}{90} & \multirow{3}{*}{10} & $0.5 \mathrm{~B}$ & 3 \\
\hline 14 & & & & $1.0 \mathrm{~B}$ & 3 \\
\hline 15 & & & & $1.5 \mathrm{~B}$ & 3 \\
\hline 16 & \multirow{3}{*}{40} & \multirow{3}{*}{90} & \multirow{3}{*}{10} & $0.5 \mathrm{~B}$ & 5 \\
\hline 17 & & & & $1.0 \mathrm{~B}$ & 5 \\
\hline 18 & & & & $1.5 \mathrm{~B}$ & 5 \\
\hline 19 & \multirow{3}{*}{\multicolumn{2}{|c|}{$68 \mathrm{dia}$}} & \multirow{3}{*}{10} & $0.5 \mathrm{~B}$ & 1 \\
\hline 20 & & & & $1.0 \mathrm{~B}$ & 1 \\
\hline 21 & & & & $1.5 \mathrm{~B}$ & 1 \\
\hline 22 & \multirow{3}{*}{\multicolumn{2}{|c|}{$68 \mathrm{dia}$}} & \multirow{3}{*}{10} & $0.5 \mathrm{~B}$ & 3 \\
\hline 23 & & & & $1.0 \mathrm{~B}$ & 3 \\
\hline 24 & & & & $1.5 \mathrm{~B}$ & 3 \\
\hline 25 & \multirow{3}{*}{\multicolumn{2}{|c|}{$68 \mathrm{dia}$}} & \multirow{3}{*}{10} & $0.5 \mathrm{~B}$ & 5 \\
\hline 26 & & & & $1.0 \mathrm{~B}$ & 5 \\
\hline 27 & & & & $1.5 \mathrm{~B}$ & 5 \\
\hline
\end{tabular}

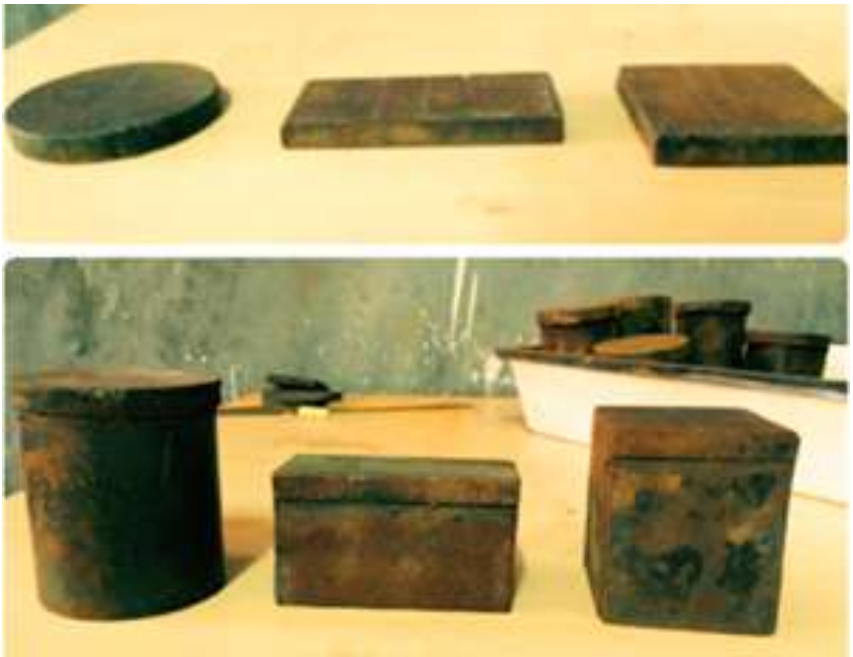

Fig 1: Model Footings

\section{2 c- $\Phi$ soil}

The soil used in the experiment program was uniform, clean soil obtained from the excavation was used in the model test. The soil was oven dried and sieved as per IS standard. The geotechnical properties of the soil used is given in Table 2 .

Table 2: Geotechnical properties of soil

\begin{tabular}{|l|l|}
\hline Property & Value \\
\hline Specific Gravity $(\mathrm{G})$ & 2.67 \\
\hline Effective Particle Size $\left(\mathrm{D}_{10}\right), \mathrm{mm}$ & 0.022 \\
\hline Particle Size $\left(\mathrm{D}_{30}\right), \mathrm{mm}$ & 0.068 \\
\hline Particle Size $\left(\mathrm{D}_{60}\right), \mathrm{mm}$ & 0.36 \\
\hline Uniformity Coefficient $(\mathrm{Cu})$ & 16.36 \\
\hline Coefficient of Curvature $(\mathrm{Cc})$ & 0.58 \\
\hline Unit Weight $(\Upsilon), \mathrm{kN} / \mathrm{m}^{3}$ & 13.73 \\
\hline Angle of internal friction & $37^{0}$ \\
\hline Cohesion $(\mathrm{c}), \mathrm{kN} / \mathrm{m}^{2}$ & 11 \\
\hline
\end{tabular}

\subsection{Test Tank and Loading Frame}

The test tank was made up of steel and has a size of $0.75 \mathrm{~m}$ (length), $0.45 \mathrm{~m}$ (width) and $0.75 \mathrm{~m}$ (depth) as shown in fig 2. Stiffeners were used to avoid buckling of side walls and the bottom of the tank during loading of the model footing. The side walls and bottom the of the tank were made up of 4 $\mathrm{mm}$ steel plate. The inside walls of the tank were smooth enough to minimize the side friction. Static vertical loads were applied to the model foundations using an electrically operated mechanical jack attached to a loading frame. Load measurements were taken using a pressure cell between the jack and the model footing and displacement was measured using the dial gauge placed on the footing. 


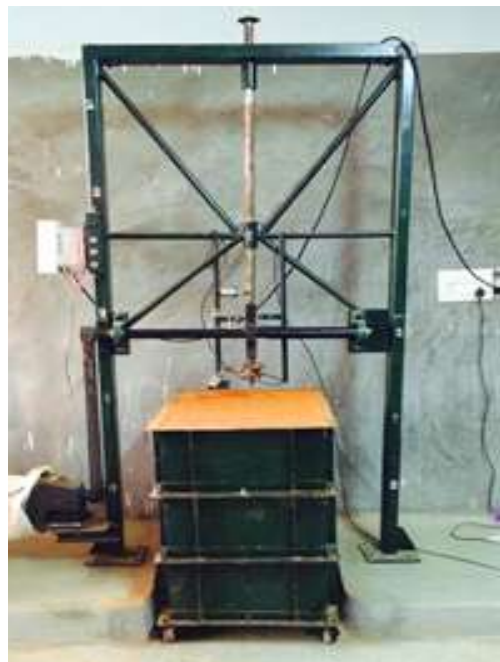

Fig 2: Test tank and loading frame

\subsection{Test Procedure}

The foundation soil bed for the testing was prepared by raining techniques and compacting soil in layers of $50 \mathrm{~mm}$ thick up to full tank height. The required relative density of soil was obtained by pouring from a pre-determined height and controlled intensity of pouring. The effect of falling height on the relative density was considered. The top of soil layer was levelled so that the model footing had full contact with the soil and that the load applied to the footing was vertical (normal). The tests were performed with the soil at unit weight of $13.73 \mathrm{kN} / \mathrm{m}^{3}$. After the completion of each test, the test pit was excavated to a depth of $1.5 \mathrm{~B}$ beneath the footing. The model footing was placed on the levelled surface of the soil at pre- determined locations in the testing tank. The vertical compressive load was gradually applied to the model footing. Then the load was measured using load cell. The load was applied at constant rate until the settlement had seized. Two numbers of dial gauges were used to measure settlements of the footing as shown in Figure 2. For each test, the load-settlement readings were recorded. The tests were continued until the settlement was reduced considerably. At the end of each test, the soil was carefully excavated.

\section{RESULTS AND DISCUSSION}

A series of pressure settlement experiments on skirted footings on $c-\Phi$ soil were performed. Results of these tests are discussed under three headings.

\subsection{Pressure - Settlement Tests for Varying Skirt}

\section{Thickness}

Figure 3 shows pressure - settlement curves for square footing without skirt and with skirts with varying skirt thickness at constant skirt depth. For concentric load in square footing, $\mathrm{d}=0.5 \mathrm{~B}$, the bearing capacity increased by $9 \%\left(4.36 \mathrm{kN} / \mathrm{m}^{2}\right.$ to $\left.4.77 \mathrm{kN} / \mathrm{m}^{2}\right)$ for $\mathrm{t}=1 \mathrm{~mm}, 56 \%(4.36$ $\mathrm{kN} / \mathrm{m}^{2}$ to $\left.6.81 \mathrm{kN} / \mathrm{m}^{2}\right)$ for $\mathrm{t}=3 \mathrm{~mm}, 119 \%\left(4.36 \mathrm{kN} / \mathrm{m}^{2}\right.$ to $9.54 \mathrm{kN} / \mathrm{m}^{2}$ ) for $\mathrm{t}=5 \mathrm{~mm}$.

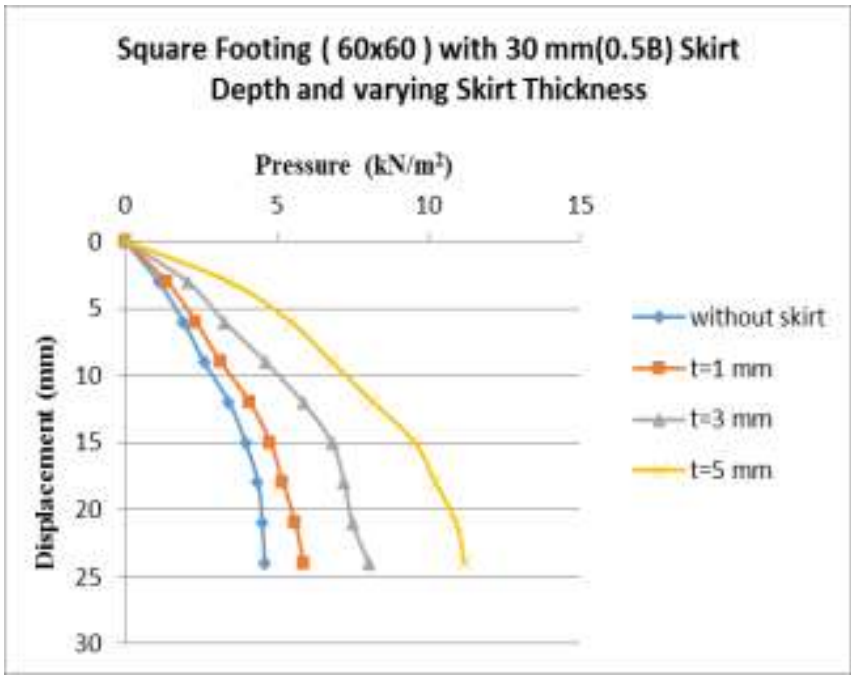

Fig 3: Pressure-Settlement curve for Square Footing with (0.5B) Skirt Depth and varying Skirt Thickness

For concentric load in square footing as shown in figure 4, the pressure - settlement curves without skirt and with skirts with varying skirt thickness at constant skirt depth, $\mathrm{d}=1 \mathrm{~B}$, the bearing capacity increased by $128 \%\left(4.36 \mathrm{kN} / \mathrm{m}^{2}\right.$ to 9.95 $\left.\mathrm{kN} / \mathrm{m}^{2}\right)$ for $\mathrm{t}=1 \mathrm{~mm}, 156 \%\left(4.36 \mathrm{kN} / \mathrm{m}^{2}\right.$ to $\left.11.17 \mathrm{kN} / \mathrm{m}^{2}\right)$ for $\mathrm{t}=3 \mathrm{~mm}, 206 \%\left(4.36 \mathrm{kN} / \mathrm{m}^{2}\right.$ to $\left.13.35 \mathrm{kN} / \mathrm{m}^{2}\right)$ for $\mathrm{t}=5 \mathrm{~mm}$.

\section{Square Footing ( $60 \times 60$ ) with $60 \mathrm{~mm}(1 \mathrm{~B})$ Skirt Depth and varying Skirt Thickness}

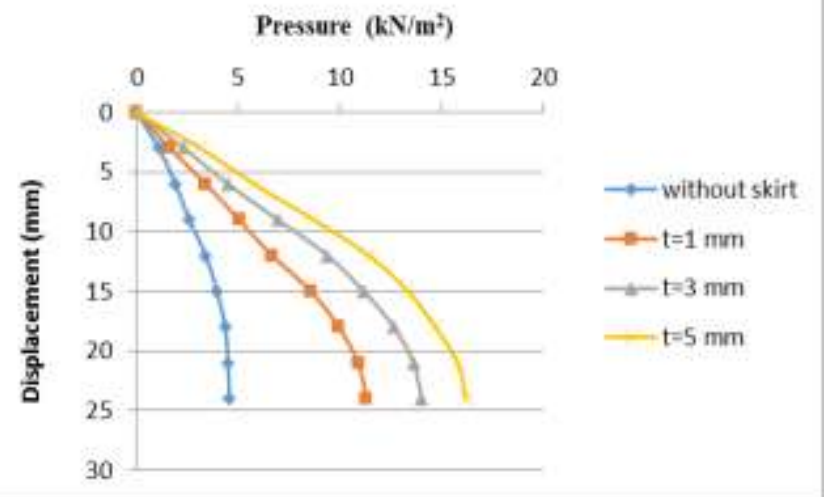

Fig 4: Pressure-Settlement curve for Square Footing with (1B) Skirt Depth and varying Skirt Thickness

\subsection{Pressure - Settlement Tests for Varying Skirt Depth}

Pressure - settlement curves shown in figure 5 is for footing without skirt and with skirts with varying skirt depth at constant skirt thickness, $\mathrm{t}=1 \mathrm{~mm}$. The bearing capacity increased by $9.4 \%\left(4.36 \mathrm{kN} / \mathrm{m}^{2}\right.$ to $\left.4.77 \mathrm{kN} / \mathrm{m}^{2}\right)$ for $\mathrm{d}=30$ $\mathrm{mm}, 128 \%\left(4.36 \mathrm{kN} / \mathrm{m}^{2}\right.$ to $\left.9.95 \mathrm{kN} / \mathrm{m}^{2}\right)$ for $\mathrm{d}=60 \mathrm{~mm}, 222 \%$ $\left(4.36 \mathrm{kN} / \mathrm{m}^{2}\right.$ to $\left.14.03 \mathrm{kN} / \mathrm{m}^{2}\right)$ for $\mathrm{d}=90 \mathrm{~mm}$. 


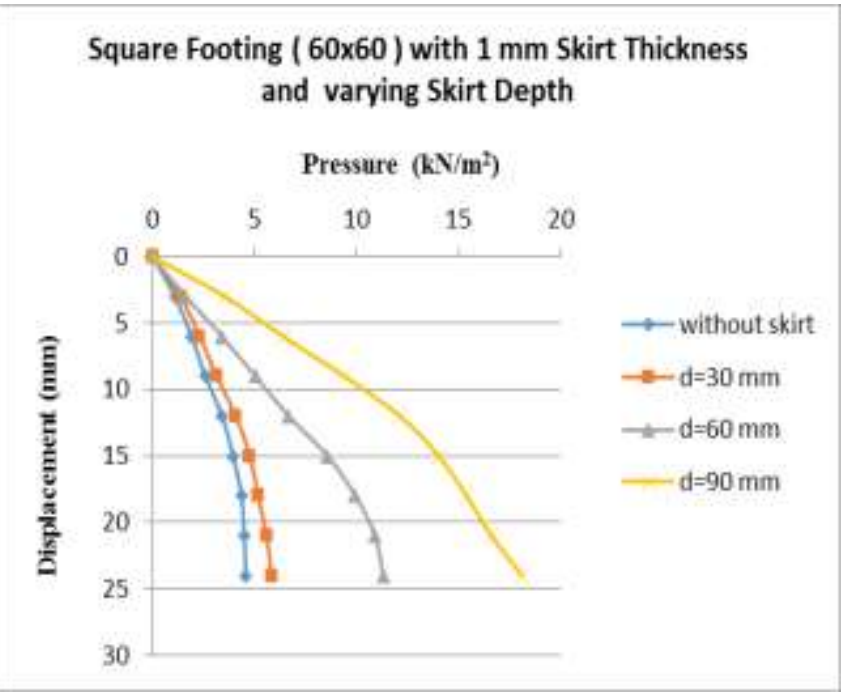

Fig 5: Pressure-Settlement curve for Square Footing with 1 mm Skirt Thickness and varying Skirt Depth

For concentric load in square footing as shown in Figure 6, pressure - settlement curves for square footing without skirt and with skirts with varying skirt depth at constant skirt thickness. For concentric load in square footing, $\mathrm{t}=3 \mathrm{~mm}$, the bearing capacity increased by $56 \%\left(4.36 \mathrm{kN} / \mathrm{m}^{2}\right.$ to 6.81 $\left.\mathrm{kN} / \mathrm{m}^{2}\right)$ for $\mathrm{d}=30 \mathrm{~mm}, 156 \%\left(4.36 \mathrm{kN} / \mathrm{m}^{2}\right.$ to $\left.11.17 \mathrm{kN} / \mathrm{m}^{2}\right)$ for $\mathrm{d}=60 \mathrm{~mm}, 487 \%\left(4.36 \mathrm{kN} / \mathrm{m}^{2}\right.$ to $\left.25.61 \mathrm{kN} / \mathrm{m}^{2}\right)$ for $\mathrm{d}=90$ $\mathrm{mm}$.

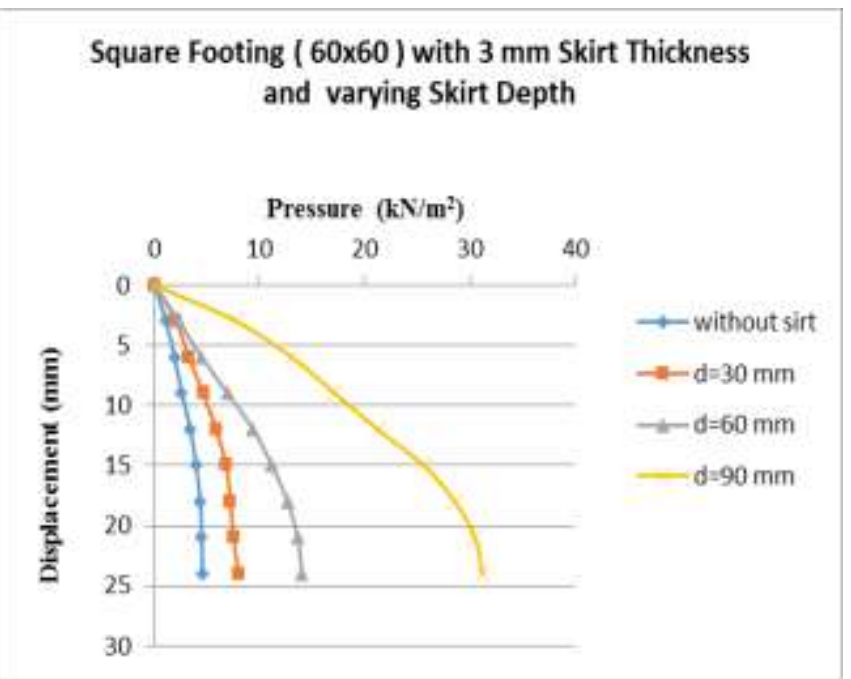

Fig 6: Pressure-Settlement curve for Square Footing with 3 mm Skirt Thickness and varying Skirt Depth

\subsection{Pressure - Settlement Tests for Varying Skirt \\ Depth}

The pressure - settlement curves for rectangular footing without skirt and with skirts with varying skirt thickness at constant skirt depth is shown in figure 7. For concentric load in rectangular footing, $\mathrm{d}=0.5 \mathrm{~B}$, the bearing capacity increased by $58 \%\left(3.54 \mathrm{kN} / \mathrm{m}^{2}\right.$ to $\left.5.59 \mathrm{kN} / \mathrm{m}^{2}\right)$ for $\mathrm{t}=1$ $\mathrm{mm}, 65 \%\left(3.54 \mathrm{kN} / \mathrm{m}^{2}\right.$ to $\left.5.85 \mathrm{kN} / \mathrm{m}^{2}\right)$ for $\mathrm{t}=3 \mathrm{~mm}, 96 \%$ $\left(3.54 \mathrm{kN} / \mathrm{m}^{2}\right.$ to $\left.6.95 \mathrm{kN} / \mathrm{m}^{2}\right)$ for $\mathrm{t}=5 \mathrm{~mm}$.

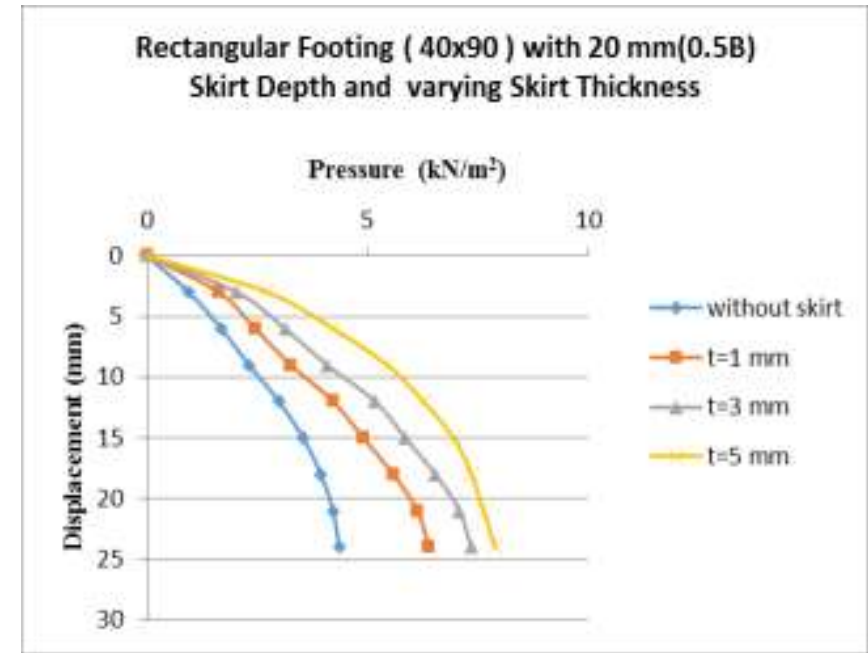

Fig 7: Pressure-Settlement curve for Rectangular Footing with $20 \mathrm{~mm}$ Skirt Depth and varying Skirt Thickness

Figure 8 shows pressure - settlement curves for circular footing without skirt and with skirts with varying skirt thickness at constant skirt depth. For concentric load in circular footing, $\mathrm{d}=0.5 \mathrm{~B}$, the bearing capacity increased by $26 \%\left(6.81 \mathrm{kN} / \mathrm{m}^{2}\right.$ to $\left.8.59 \mathrm{kN} / \mathrm{m}^{2}\right)$ for $\mathrm{t}=1 \mathrm{~mm}, 46 \%(6.81$ $\mathrm{kN} / \mathrm{m}^{2}$ to $\left.9.94 \mathrm{kN} / \mathrm{m}^{2}\right)$ for $\mathrm{t}=3 \mathrm{~mm}, 68 \%\left(6.81 \mathrm{kN} / \mathrm{m}^{2}\right.$ to $11.44 \mathrm{kN} / \mathrm{m}^{2}$ ) for $\mathrm{t}=5 \mathrm{~mm}$.

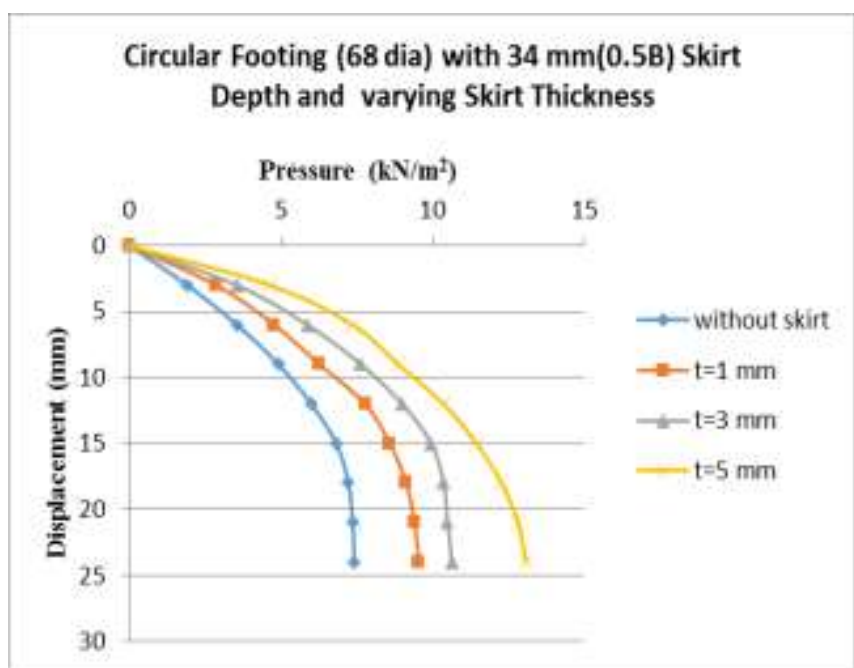

Fig 8: Pressure-Settlement curve for Circular Footing with $34 \mathrm{~mm}$ Skirt Depth and varying Skirt Thickness.

\section{CONCLUSION}

In conclusion, the test results show that vertical insertion improved bearing capacity of skirted footings for parameters such as thickness and depth of skirts and shape of footing. As thickness of vertical insertion increases, bearing capacity also increased. For concentric load in square footing $t=1$ $\mathrm{mm}, 3 \mathrm{~mm}$ and $5 \mathrm{~mm}$, the bearing capacity improved by 2,4 and 8 times respectively for $\mathrm{d}=1.5 \mathrm{~B}$. As the depth of vertical insertion increases, bearing capacity also increases for example, for concentric load in square footing $\mathrm{d}=0.5 \mathrm{~B}, 1 \mathrm{~B}$ and $1.5 \mathrm{~B}$ the bearing capacity improved by 1,2 and 8 times respectively for $\mathrm{t}=5 \mathrm{~mm}$. Test results clearly indicate that the optimal depth of vertical insertion is $1.5 \mathrm{~B}$. The trend is 
similar for almost all cases. For square footing, the improvement is up to 8 times, 6 times for rectangular footing and 4 times for circular footing. The optimal shape of footing is square footing as observed.

\section{REFERENCES}

[1] Hugo E. Acosta-Martinez, Susan M. Gourvenec, and Mark F. Randolph, (2008) An Experimental Investigation of a Shallow Skirted Foundation under Compresssion and Tension, Soils and Foundations, vol. 48, no. 2, pp. 247-254, Japanese Geotechnical Society.

[2] Igor L. Boiko and Musa Alhassan (2013), Effect of Vertical Cross-Sectional Shape of Foundation on Settlement and Bearing Capacity of Soils," in Procedia Engineering, vol. 57, pp.207-212, ISSN,1877-7058.

[3] B. W. Byrne, F. Villalobos, G.T. Houlsby, and C.M. Martin (2003), Laboratory testing of shallow skirted foundations in sand, British Geotechnical Association Int. Conf. on Foundations, vol. 2, Dundee, pp. 161-173.

[4] Dr. Mohammed Y. Fattah, Dr. Kais T. Shlash, and Husham A. Mohammed (2015), Experimental Sudy on the Behavior of Bounded Square Footing on Sandy Soil, Eng. \& Tech. Journal, vol. 32, pp. 1083-1105, Part (A), No. 5.

[5] S. Golmoghani-Ebrahimi and M.A. Rowshanzamir, (2013) Experimental Evaluation of Bearing Capacity of Skirted Footings, Civil Engineering and Architecture, vol. 1(4), pp. 103-108, 2013, doi: 10.13189/cea.2013.010401.

[6] Nihat Kaya and Murat Ornek (2013), Experimental and Numerical Studies of T-shaped Footings, ACTA Geotechnica Slovenica, vol. 1,

[7] L. Boiko M. Alhassan (2015), Experimental Study of the Effect of Foundation Shape on Settlement and Bearing Capacity of Soils, International Journal of Engineering \& Technology, vol. 3, no. 2, ISSN 20493444.

[8] Kurian P Nainan (2005), Design of Foundation Systems, 3rd ed.: Narisa publishing house,

[9] S. P. Singh, S. Tripathy, and B. Srikanth (2013), Horizontal Load Carrying Capacity of Circular Skirted Footings Embedded in Sand, in Indian Geotechincal Conference, Roorkee, December 22-24.

[10] Swami Saran (2006), Analysis and Design of Substructures, limit state design, 2nd ed.: Oxford \& IBH publishing Co. Pvt. Ltd.

[11] Amr Z. EL Wakil (2013), Bearing capacity of Skirt circular footing on sand, Alexandria Engineering Journal, vol. 52, no. 3, pp. 359-364, ISSN 1110-0168. 